\title{
O projeto de vida ética no escrito $A$ Constituição da Alemanha do jovem Hegel*
}

\author{
The ethical life project in young Hegel's writing The Constitution \\ of Germany
}

$\frac{\text { Roberta Bandeira de Souza }}{\text { betalogos@gmail.com }}$

(Universidade Federal de Minas Gerais, Minas Gerais, Brasil)

\begin{abstract}
Resumo: Este artigo analisa algumas passagens do escrito $A$ Constituição da Alemanha que revelam o conceito embrionário do jovem Hegel de vida ética. Inicialmente, apresenta a tensão entre a antiga Constituição imperial e a sociedade moderna que impedia a unificação do povo alemão. Em seguida, indica os elementos da antiga Constituição que precisavam ser revitalizados na Alemanha do século XIX para existir a conciliação dos direitos privados e públicos. Por fim, explicita o debate travado pelo jovem Hegel com os jusnaturalistas e os positivistas, que tinha como propósito apreender o sentido especulativo da vida ética absoluta.
\end{abstract}

Palavras-Chave: Constituição; vida ética; jovem Hegel; direitos.
Abstract: This article analyzes some passages of the writing The Constitution of Germany that reveal young Hegel's embryonic concept of ethical life. Initially, it presents the tension between the old imperial Constitution and the modern society that prevented the unification of the German people. It then indicates the elements of the old Constitution that needed to be revitalized in the nineteenthcentury Germany in order to reconcile private and public rights. Finally, it explains the debate held by the young Hegel with the jusnaturalists and the positivists, whose purpose was to grasp the speculative sense of absolute ethical life.

Keywords: Constitution; ethical life; young Hegel; rights.

DOI: http://dx.doi.org/10.11606/issn.2318-9800.v23i2p105-119

\section{A vida ética ocultada no conflito entre as ruínas da constituição feudal e a necessidade de modernização do povo alemão}

A Constituição da Alemanha (CA) [Die Verfassung Deutschlands (VD)] começou a ser esboçada pelo jovem Hegel no período final de Frankfurt (1799-1800) e ganha

\footnotetext{
* Este artigo é uma adaptação da primeira parte do primeiro capítulo de minha Tese de Doutorado: Cf. Souza, R. B. de. Intuição e conceito na vida ética. Tese (Doutorado). Programa de Pós-Graduação em Filosofia, Faculdade de Filosofia e Ciências Humanas, Universidade Federal de Minas Gerais, Belo Horizonte, 2016.
} 
sua versão definitiva apenas em Jena, entre os anos de 1801 e $1802 .{ }^{1}$ Pode-se dizer que o propósito central do ensaio é apresentar como a dissolução da contradição entre a antiga Constituição do Sacro Império Romano da Nação Germânica (Império alemão) e a sociedade alemã moderna poderia ser a condição para a organização do Estado alemão justo e livre, quer dizer, para a constituição de uma autêntica vida ética. Tendo essa finalidade, o jovem Hegel discute com algumas concepções jurídicas vigentes na sua época e conclui a necessidade da liberdade do povo alemão se configurar em um sólido sistema político representativo. Como nosso objetivo não é analisar todos os desenvolvimentos da $C A$, argumentaremos apenas em torno de alguns pontos que indicam o desvelamento do sentido da vida ética nesse escrito.

Desde cedo, o jovem Hegel é contra a concepção mecanicista de Estado. Mesmo sem sabermos ao certo até que ponto o filósofo contribuiu intelectualmente na elaboração do fragmento $O$ mais antigo programa de Sistema do Idealismo Alemão [Das älteste Systemprogramm des deutschen Idealismus (1797-1798)], podemos conjeturar à luz da $C A$ como ele retoma criticamente a noção minimalista do Estado mecânico esboçada no Programa. ${ }^{2}$ Estamos nos referindo especificamente à passagem:

Começando pela ideia da humanidade, quero mostrar que não há ideia no

1 Sobre o pensamento político do jovem Hegel no período de Frankfurt, escreve Bernard Bourgeois: "Em Frankfurt, uma das cidades mais comerciais da Alemanha, Hegel percebe a vitalidade original do mundo moderno, que exclui toda repetição do passado no pressente. Seu projeto continua sendo a criação para o homem de um 'em si' de liberdade, mas a liberdade do homem moderno não poderia reproduzir a do cidadão antigo. No Estado moderno, imensamente maior que a república antiga, o indivíduo não pode mais se identificar ao universal imediatamente, mas apenas por mediações que afrouxam a identidade do cidadão e do Todo estatal, constitutiva da liberdade. Contudo, se essa identidade que não é mais imediata é tanto menos forte quanto as determinações que a mediatizam não são organizadas racionalmente para apagar o corte entre o cidadão e o Estado, a causa disso é também uma indiferença em relação ao Estado, decorrente do fato do homem moderno não encontrar mais sua liberdade, sua 'morada', no Todo nacional, mas na esfera limitada da propriedade privada" (Bourgeois, 2000, p. 63). É neste contexto de separação entre o indivíduo e o Estado, entre o privado e o público, que Hegel inicia a elaboração da A Constituição da Alemanha, escrito publicado pela primeira vez somente em 1893.

2 Durante o século XX, alguns estudiosos do idealismo alemão debateram sobre a autoria do texto 0 mais antigo programa de sistema do Idealismo Alemão. Franz Rosenzweig nomeou e publicou o texto pela primeira vez em 1917. Mesmo sem ter dúvida de que o fragmento havia sido escrito por Hegel, Rosenzweig atribuiu a Schelling as ideias ali expostas e especulou que o texto havia sido escrito entre abril e agosto de 1796. Desde a publicação do Programa por Rosenzweig, outras hipóteses foram levantadas sobre a real autoria do fragmento. Wilhem Böhn, em 1926, afirmou ser Hölderlin o autor do texto. Já entre os anos de 1965 e 1969, Otto Pöggeler e Klaus Düsing concordaram que não apenas a letra, mas também as ideias ali expostas eram de Hegel. Segundo Joãosinho Beckenkamp, atribuir a Hegel as reflexões contidas no Programa é importante para compreender o conteúdo do pensamento do jovem filósofo antes do período sistemático: "No caso de Hegel, o texto é fundamental para lançar luz sobre o seu desenvolvimento em Berna e Frankfurt, portanto no período anterior a Jena [...]. Só com o avanço do estudo destes textos foi se tornando claro que eles têm sua motivação em uma apropriação e superação da filosofia kantiana, o que significa seu resgate para a pesquisa filosófica do desenvolvimento do jovem Hegel. Neste contexto, o fragmento de um programa de sistema é um documento precioso para os hegelianos, por permitir uma articulação dos interesses filosóficos de Hegel no período em questão" (Beckenkamp, 2004, p.203). 
Estado, porque o Estado é algo mecânico, tampouco quanto há uma ideia de uma máquina. Apenas o que é objeto da liberdade chama-se ideia; portanto temos de ir além do Estado! Pois todo Estado - tem de tratar homens livres como engrenagem mecânica; e isso ele não deve fazer; portanto, ele deve acabar. [...] Ao mesmo tempo, quero expor aqui os princípios para uma história da humanidade e desnudar inteiramente toda a miserável obra humana de Estado, constituição, legislação (Hegel, 2004, p. 204-205).

Se além da letra, Hegel realmente empresta alguma reflexão ao fragmento, talvez a ideia de Estado possa nos indicar isso. ${ }^{3}$ Tal impressão parte da leitura da $C A$, na qual é decretada a falência da Constituição do Estado alemão (Império alemão) na transição do século XVIII para o XIX. No Programa, o Estado é acusado de tratar os homens como meras peças de uma engrenagem, como indivíduos que funcionam apenas para manter a falsa ideia da totalidade ético-política. Falsa porque na verdade o que existe são indivíduos atomizados interessados em se protegerem economicamente à sombra da autoridade estatal limitadora. Mas os homens são essencialmente livres e isso precisa ser considerado urgentemente na construção da autêntica obra humana. Tratando os homens sob o equívoco da restrita liberdade econômica, o Estado não pode ser essa obra, já que não se assenta nas ideias de humanidade e liberdade integral. Portanto, para efetivar a liberdade na história é preciso mostrar toda a falácia que está por trás do Estado construído em nome dos interesses privados, pois, longe de ser a totalidade ética libertadora da humanidade, ele se configura como a miserável unidade mecânica de seus membros. ${ }^{4}$

Diante da interpretação acima, parece que Hegel não nutre qualquer esperança do homem ser verdadeiramente livre no Estado, porém essa não é a sua conclusão definitiva. Mesmo sem abrir mão da crítica ao Estado alemão da sua época, o filósofo, ao longo dos anos de Jena, se aproximará cada vez mais da noção de Estado como a instituição ética realizadora da liberdade subjetiva e objetiva dos

3 Confirmando a ideia de que o Estado é encarado como máquina nas novas teorias jurídicas predominantes em seu tempo, afirma o jovem Hegel na CA: "Mas, o prejuízo principal das novas teorias, em parte realizadas, reside em que o Estado consiste em uma máquina com mola única que transmite o movimento para todo o resto da maquinaria infinita. Todas as instituições, que a sociedade naturalmente traz consigo, devem partir da autoridade pública suprema, pela qual devem ser reguladas, mandadas, vigiadas e dirigidas" (Hegel, 1971, p. 481; 1972, p.32). A tradução das citações da Die Verfassung Deutschlands é cotejada com a versão espanhola La Constitucion de Alemania de Dalmacio Negro Pavon e revisada pelo Prof. Dr. Leonardo A. Vieira.

$4 \mathrm{Na}$ leitura de Beckenkamp, a crítica ao Estado mecânico, supostamente realizada por Hegel, é influenciada pela reação de Kant e de outros filósofos iluministas ao Estado monárquico: "Por trás da distinção entre um Estado como um todo orgânico e como algo mecânico, encontra-se o ideário político iluminista, que passa a exigir um Estado como representante da vontade do povo, portanto determinado internamente pela vontade popular e não pelo arbítrio de um monarca. Em termos de teoria política, reage-se com isto à ideia hobbesiana do Estado como autônomo ou máquina que se move por um mecanismo interno, tal qual um relógio. Como mostra M. Frank, a crítica ao Estadomáquina tem uma longa tradição no século XVIII, tendo por expoente Rousseau. No fim do século XVIII, a crítica ao Estado-máquina se junta à reflexão sobre a nova forma do Estado inaugurada com a Revolução Francesa" (Beckenkamp, 2004, p. 203). 
cidadãos. A proposta embrionária de denunciar os limites do Estado e de refletir como a instituição estatal pode garantir a liberdade integral dos indivíduos é melhor entendida na leitura da A Constituição da Alemanha.

A CA é escrita em meio a muitos acontecimentos histórico-políticos. ${ }^{5}$ Dentre esses, temos o Congresso de Rastatt (1797-1799), no qual a Áustria se comprometeu a entregar à República Francesa os territórios alemães à margem esquerda do rio Reno. Posteriormente, é assinado o tratado de paz de Luneville (1801), que garantiu definitivamente o reconhecimento austríaco da supremacia francesa nos territórios até então disputados. ${ }^{6}$ Tais episódios representavam a destruição do Império alemão medieval, fato que só viria a se consumar em 1806 após a invasão de Napoleão a Jena ${ }^{7}$, além de prenunciarem a organização do Estado alemão unificado. Assim, é com o tom de despedida ao velho Império e certa esperança política em relação aos tempos vindouros que o jovem Hegel redige a $C A$.

Inicialmente, devemos esclarecer como o jovem Hegel conceitua a categoria de Constituição (Verfassung). Essa não se refere apenas ao conjunto de leis positivas que regulamentam os direitos privados das províncias e seus habitantes, mas é a forma organizadora dos indivíduos no Estado, assim, a Constituição é o direito público que submete as partes da sociedade à totalidade orgânica estatal. ${ }^{8}$ Essa totalidade é o que Hegel chamará mais tarde de vida ética. Partindo dessa definição, o interesse de

5 Para obter um panorama geral do contexto político-histórico no qual foi redigida a $C A$, cf. o artigo "El Pensamiento político del joven Hegel" de J.L. Hernándes. No intuito de ter um comentário mais detalhado da situação política da Alemanha e do amplo referencial teórico apropriado pelo jovem Hegel para escrever a CA, conferir as esclarecedoras introdução e notas de Delmiro Negro Pavón na sua tradução espanhola para esse escrito.

6 CA, p.59. "Por último, a paz de Luneville [1801] não somente despojou a Alemanha de muitos direitos de soberania na Itália, mas também separou dela toda a margem esquerda do Reno, diminuindo inclusive o número de seus príncipes e estabelecendo a base para diminuir ainda mais o número de seus estados, fazendo temível, para o todo e para os estados pequenos, as partes singulares da mesma" (VD, p. 503).

$7 \mathrm{Em}$ carta enviada ao amigo Niethammer, Hegel expõe sua admiração pela figura de Napoleão Bonaparte: "Vi o Imperador - essa alma do mundo - deixar a cidade para fazer o reconhecimento das suas tropas; é efetivamente uma sensação maravilhosa ver um indivíduo semelhante que, concentrado assim em um ponto, montado em seu cavalo, estende-se sobre o mundo e o domina" (Hegel, 1990, p.114-115). Hegel cultivava certa esperança de que Napoleão finalmente traria a modernização para a Alemanha e, consequentemente, a estabilidade e a liberdade políticas já muito aguardadas pelo povo alemão. Todavia, não foi bem isso o que aconteceu. Após a derrota de Napoleão em 1813, a reforma política alemã não passou de promessa, e as ideias revolucionárias foram reprimidas. A decepção de Hegel com a derrota do imperador pode ser sentida em outra carta enviada a Niethammer em 1814: "Coisas grandes aconteceram em torno de nós. É um espetáculo horroroso e prodigioso ver um enorme gênio destruir-se. É a coisa mais trágica. A mediocridade aparece em todo o seu peso" (idem, p. 31).

8 Segundo Bobbio: "Para Hegel, a Constituição não é uma lei ou um conjunto de normas jurídicas. Com a linguagem da teoria jurídica moderna, diríamos que Hegel tem uma concepção 'institucional' da Constituição. Da concepção da Constituição como lei suprema deriva a teoria política do constitucionalismo: não há nada mais alheio ao pensamento de Hegel do que o ideal de constitucionalismo, isto é, do Estado limitado pelo direito, ou em outros termos, do Estado fundado na rule of law, no sentido anglo-saxão da expressão" (Bobbio, 1989, p.97). 
Hegel era diagnosticar qual a situação real da Constituição da Alemanha na sua época. Segundo N. Bobbio: “de resto, já na Verfassung Deutschlands, o problema político central que Hegel se tinha posto era o da dissolução consumada e da restauração esperada de uma Constituição do Império alemão, entendida como organização do todo" (Bobbio, 1989, p. 98). Portanto, o filósofo expôs tanto os aspectos da Constituição imperial já dissolvidos naquela época como também apresentou os princípios que necessitavam ser restaurados para que a Alemanha pudesse se organizar enquanto verdadeiro Estado constitucional. ${ }^{9}$

Discordando de I. Kant pela sua extrema valorização da premissa jurídica Fiat justitia, pereat mundus (Faça-se justiça, ainda que o mundo pereça), ${ }^{10}$ Hegel repudia a tendência do direito alemão de seguir o preceito Fiat justitia, pereat Germania [Faça-se justiça, ainda que a Alemanha pereça] (VD, p. 470; Hegel, 1972, p.32). Nesse sentido, o jovem Hegel não compactua com a noção de justiça como aplicação impiedosa da lei, imposta independentemente das circunstâncias históricas de um Estado e da vontade de seus cidadãos. Ao contrário disso, entende a justiça como a organização de determinado Estado em torno das exigências subjetivas e objetivas de seu povo de modo que todos os interesses individuais, protegidos pelo direito privado, sejam submetidos ao interesse universal do Estado, resguardado pelo direito público. Logo, Hegel não poderia estar de acordo com a máxima Fiat justitia, pereat Germania, pois, além do direito abstrato, existe a vida concreta da comunidade ética, os costumes e os sentimentos do povo, devendo tudo isso ser considerado na elaboração da Constituição do Estado alemão.

Ao ler o seu tempo com acuidade, o jovem de Jena identifica a tensão entre a antiga Constituição do Império alemão e a nova formação político-econômica dos desunidos territórios alemães. Enquanto alguns países europeus já haviam reconfigurado a sociedade, o Estado, o direito e a economia de acordo com a nova racionalidade moderna, o aglomerado de territórios alemães estavam desorganizados em todos esses aspectos, pois o que prevalecia era a contradição entre a Constituição feudal do passado e a sociedade do presente.

9 Importante ressaltar que o verdadeiro Estado constitucional pensado por Hegel é diferente daquele defendido pelos juristas no período da Revolução Francesa. Os revolucionários articularam o Estado constitucional a partir das singularidades isoladas. Hegel, ao contrário, concebe a Constituição do Estado como a organização legítima do povo. Conforme Bobbio: "Portanto, a Constituição, como organização do todo, é a forma específica em que as várias partes do povo são chamadas a cooperar, ainda que desigualmente, para um único fim, que é o fim superior do Estado, diferente do fim dos indivíduos singulares" (Bobbio, 1989, p. 99).

$10 \mathrm{Na}$ interpretação de Kant: "Esta proposição quer apenas dizer que as máximas políticas não devem derivar do bem-estar ou da felicidade que cada Estado, aguardadas como consequências de sua aplicação, por conseguinte não derivam do fim que cada Estado para si estabelece como objeto (do querer), como princípio supremo (mas empírico), da sabedoria política, mas do puro conceito do dever jurídico (da obrigação moral, cujo princípio é dado pela razão pura), sejam quais forem as consequências físicas que se pretendam" (Kant, 2002, p. 162). 
De um lado, existiam os estados (territórios/províncias) alemães independentes comandados por príncipes nacionais que usufruíam dos bens públicos como se fossem bens privados. Estes nobres tinham o interesse de enriquecer cada vez mais à custa dos resquícios das relações de submissão feudal. De outro lado, encontrava-se o crescente desejo do povo pela centralização do Estado alemão e a necessidade da criação da nova unidade política que preservasse a liberdade econômica, entendida como a garantia dos direitos privados de todos os indivíduos. ${ }^{11}$ Diante da ambiguidade de interesses, o jovem Hegel constata a ruptura definitiva entre o destino da antiga Constituição feudal e o destino da sociedade alemã que despontava no mundo moderno. Assim afirma: "o edifício no qual habita aquele destino não é mais suportado pelo destino da geração atual e está, indiferente e desnecessário a seus interesses e atividade, isolado do espírito do mundo" (Hegel, 1972, p.13). Enquanto os antigos princípios feudais insistiam em determinar a vida do povo, a geração daquele tempo não suportava mais ser submissa àquela Constituição isolada do Espírito do mundo (Geist der Welt), ou seja, separada das noções modernas de Estado, de direito e de liberdade. Nem mesmo a Revolução Francesa, tendo disseminando em terras alemãs a possibilidade do Estado centralizado baseado nos ideais de liberdade, igualdade e fraternidade, conseguiu propiciar a criação da Constituição que organizasse o povo alemão de acordo com as exigências da época. ${ }^{12}$

11 Comparando o processo de centralização do poder ocorrido em alguns países europeus com a situação da Alemanha no século XVIII, afirma Norbert Elias: "no caso de países como a França, Inglaterra, Suécia e até a Rússia, a sociedade medieval de Estados feudais passou por um contínuo processo de transformação em Estados do tipo mais compactamente integrado de monarquia absoluta, que era usualmente mais forte nas lutas de poder. Na Alemanha, o equilíbrio de forças afastou-se gradualmente do nível de integração representado pelo imperador e inclinou-se a favor do de príncipes regionais. Em contraste com crescente centralização do poder em outros países europeus, o império germânico (ou Sacro Império Romano) sofreu a decadência do poder central. 0 caso dos Habsburgo mostra com muita clareza de que forma o seu poder como imperadores passou a depender cada vez mais dos recursos que sua própria base de poder alodial ou familiar colocava à disposição deles. No transcorrer dos séculos, o Estado imperial medieval foi perdendo cada vez mais sua função. Já no século XVIII as lutas de eliminação eram deflagradas no interior de suas fronteiras entre os reis da Prússia e os governantes Habsburgo da Áustria" (Norbert, 1997, p. 18).

12 Existem inúmeras interpretações sobre a relação de Hegel com a Revolução Francesa. Os alemães Joachim Ritter e Jürgen Habermas, por exemplo, chegaram a conclusões divergentes sobre o assunto. Enquanto Ritter defendeu que Hegel compreendeu corretamente os desdobramentos políticos afirmativos e negativos do ideal de liberdade trazido com a Revolução Francesa; Habermas afirmou que a leitura hegeliana da Revolução Francesa é essencialmente ambígua. Isso porque, se em alguns dos textos de Jena, o jovem Hegel esboçou uma teoria da intersubjetividade como alternativa ao modelo de liberdade negativa exaltada com o Terror revolucionário, nos anos seguintes, Hegel optou pela concepção de espírito do mundo (absoluto) que se autoproduz historicamente, tendo tal teoria como consequência a perda do vínculo entre a história do indivíduo e a história da comunidade política (cf. Ritter, 1970, p. 5-64; Habermas, 2013, p. 201-219). No Brasil, Manfredo Oliveira e Luiz Bicca também interpretaram o posicionamento hegeliano frente à Revolução Francesa. M. Oliveira, de modo similar a Ritter, opta pelo argumento do sentido afirmativo e negativo atribuído por Hegel aos princípios revolucionários: "por um lado, um grande entusiasmo que provém da consideração dos princípios fundamentais que estão em jogo neste acontecimento; por outro lado, uma crítica radical à parcialidade destes princípios, o que fez dele um profundo adversário do pensamento liberal, tendo sido Hegel um dos primeiros filósofos 


\section{O ser e o dever ser do Estado alemão}

Analisando o conflito entre a Constituição existente e a Constituição que deveria ser instaurada, o jovem Hegel irá afirmar de modo categórico: "A Alemanha não é mais um Estado" (VD, p. 461; Hegel, 1972, p.8). Isto porque "uma multidão de seres humanos somente pode ser chamada de Estado se estiver unida para a defesa comum da totalidade de sua propriedade" (idem, p.22). O fundamental na afirmação é a constatação de que na Alemanha o direito público foi dissolvido no direito privado. ${ }^{13}$ Os vários estados alemães, nascidos da repartição aleatória de propriedades imperiais, legislavam de acordo com seu arbítrio e em favor dos seus interesses particulares (cf. CA, p. 18-19; VD, p.470-471). Essa multiplicidade de territórios eram individualidades isoladas que se associavam mecanicamente umas às outras apenas para estabelecer acordos formais de sobrevivência (cf. CA, p. 61; VD, p. 502). Por não terem qualquer estabilidade política interior e exterior, ${ }^{14}$ os estados eram

iguais a um monte de pedras redondas que se amontoam formando uma pirâmide, um monte, no entanto, que se desfaz ou, ao menos, nenhuma resistência pode opor, porque aquelas pedras são absolutamente redondas e devem permanecer sem nenhum encaixe, tão logo a pirâmide começa a mover-se para a finalidade para a qual se formou (VD, p. 504; Hegel, 1972, p.62).

Como poderia a Alemanha ser chamada de Estado se ela não se organizava sobre o princípio da unidade? Se a antiga Constituição do Império não conseguia mais organizar os vários estados alemães sob uma forte totalidade política? Se o primordial era a defesa do direito privado e não do direito público? No intuito de responder aos questionamentos, a $C A$ mostra a urgência de unir os vários estados alemães em nome da autêntica vida coletiva, isto é, da vida ética. Assim, insiste na criação do Estado alemão unificado e clama pela revitalização de alguns princípios da Constituição feudal, de modo que esta apareça como direito público interessado

do Ocidente a tematizar as contradições fundamentais da sociedade que emergiu da Revolução. Assim, poder-se-ia dizer que todo pensamento político de Hegel é um afirmar e negar a Revolução, como o parto de uma sociedade nova" (Oliveira, 1993, p.228). L. Bicca, por sua vez, também seguindo o raciocínio de Ritter, identificou que o desafio traçado por Hegel à Revolução Francesa, a saber, a efetivação da liberdade, ainda não foi superado: "a vida de Hegel acompanha toda a trajetória da revolução. Sua filosofia, como bem observa Ritter, expressa o desafio posto por este evento ao pensar. $O$ problema posto por ela e até hoje ainda não resolvido em sua totalidade é o da efetiva realização da liberdade" (Bicca, 1997, p. 95).

13 Diante da submissão do direito da totalidade a particularidades atomizadas, Hegel diz que "se Alemanha pudesse ser considerada um Estado, sua situação política deveria ser considerada como uma anarquia jurídica e seu direito estatal como um sistema de direito contra o Estado" (CA, p. 18-19; VD, 470).

14 Conforme Bobbio: "se a Alemanha não é mais um Estado, isto depende do fato que os príncipes alemães exercem os poderes públicos, tanto interna, quanto externamente, como se fossem direitos privados; o que podem fazer na medida em que não existe mais, acima dos singulares, uma Constituição do império, entendida como organização do todo" (Bobbio, 1989, p.58-59). 
principalmente em assegurar a totalidade.

Não sem razão, Hegel revela sua aversão à noção liberal e burguesa de que a preocupação central do Estado deve ser a proteção jurídica dos direitos privados. Ao contrário, a instituição estatal precisa se estabelecer como poder central, que tem como meta afirmar a si mesmo enquanto unidade política. Nas palavras de Hegel:

O Estado exige um centro, um monarca e estamentos, nos quais se concentrariam os poderes mais diversos, os assuntos estrangeiros, o exército, as finanças, que têm relação com tudo isto etc.; um centro que, além da direção, teria o poder necessário para afirmar a si mesmo e suas decisões, manter as partes singulares em dependência de si (VD, p. 469; Hegel, 1972, p.17).

Tal concepção de Estado apresenta a tentativa de se reunir com o tempo, algo que será buscado por Hegel durante o período de Jena. Ao defender a centralização estatal, o filósofo valoriza a restauração do exército único comandado pela figura do imperador, algo já enfraquecido na desorganizada Alemanha do fim do século XVIII, mas que deveria ser retomado com o intuito de estabelecer o Estado alemão protetor do direito público. Esse Estado somente "seria realizado caso todo aparato militar da Alemanha fosse reunido em um exército (VD, p. 578; Hegel, 1972, p.149). Contudo, o reestabelecimento do exército imperial não significava simplesmente destruir a esfera dos interesses privados já consolidada na época moderna, na verdade, representava a necessidade da força militar de garantir a segurança externa e interna do Estado, de modo que os interesses econômicos dos indivíduos fossem garantidos sem ameaçar a organização do povo (Bourgeois, 2000, p. 71).

Nas intepretações de B. Bourgeois e F. Rosenzweig, o jovem Hegel, ao considerar a força militar como elemento unificador do interesse privado e público, apresenta o retrato do Estado alemão da sua época. Na obra Hegel e Estado, afirma Rosenzweig: "é o Estado do século XVIII que se apresenta, com sua fresca vontade de potência [...]. Poder, poder, e mais uma vez poder encontra-se talhado sob o portal desse edifício” (Rosenzweig, 1920, p.186). Corroborando com essa noção, enfatiza Bourgeois na obra $O$ pensamento político de Hegel: "O Estado é força, e força militar; todas as suas outras características são secundárias. Esse Estado-força é de fato o Estado da época com a sua vigorosa vontade de potência" (Bourgeois, 1969, p. 70). Porém, Bourgeois e Rosenzweig chamam atenção para o fato de que a reconciliação feita pelo jovem Hegel com o tempo não consistia simplesmente em dizer o que é, em analisar empiricamente o Estado alemão do fim do século XVIII, mas também significava valorizar aquilo que surge contra ele, no caso, a sociedade liberal. Portanto, a organização do Estado alemão dependia tanto da "renovação radical” (Rosenzweig, 2008, p. 201) da totalidade orgânica do antigo Império quanto da "cuidadosa manutenção" dos novos valores do mundo moderno (idem, ibidem).

Hegel constata que a revitalização do Império somente aconteceria "no caso 
em que um poder estatal fosse organizado e o povo alemão reestabelecesse relação com o imperador e com o Império" (VD, p. 577; Hegel, 1972, p.149). A representação do povo junto ao imperador era a provável solução para que o aglomerado de estados alemães, preocupados apenas com os seus direitos privados, despertassem o interesse para unificar a Alemanha. Segundo Hegel: "é preciso que se adquira, entre as províncias, alguma espécie de cooperação para o todo" (idem, ibidem). Entretanto, a Alemanha estava longe de se organizar como totalidade, já que as pequenas províncias se associavam às grandes potências apenas para não sucumbirem perante à instabilidade política da época e não porque entendiam a necessidade da unificação do povo alemão. Logo, a liberdade alemã não ajudou na configuração da antiga Constituição no Estado centralizado, ${ }^{15}$ pois tal liberdade enaltecia o sentimento originário de independência dos indivíduos em relação à coletividade e, consequentemente, incentivava o distanciamento dos estados do poder imperial:

A Alemanha não estruturou, em relação a si própria, o princípio que deu ao mundo, nem soube encontrar nele seu apoio. Não se organizou de acordo com ele, e sim se desorganizou, posto que não configurou a Constituição feudal em um poder estatal e quis permanecer completamente fiel a sua índole original de independência da individualidade, a respeito da universalidade, em relação ao Estado. Se diluiu em vários estados, cujo modo de subsistir depende de solenes tratados entre eles e é garantido por grandes poderes. Esse modo de subsistir não se apoia, no entanto, em poder e força próprios, e sim depende da política das grandes potências (idem, p.102).

Nesse cenário, onde prevalece a independência dos estados em relação ao Império e dos indivíduos em relação ao povo, os direitos públicos são transformados em direitos privados e o resultado é o enfraquecimento de outro princípio originário dos alemães: a monarquia representativa. ${ }^{16}$

O Estado alemão original (Império) se constituía como poder político no qual assuntos eram conduzidos com o auxílio dos representantes do povo. Todavia, no início do século XIX, tal Estado não existia mais, sendo apenas obra do pensamento. O Império, no qual era estabelecida a relação dos representantes do povo com o poder monárquico, tendo em vista a realização de assuntos públicos, não passava de ideia morta. Nas palavras de Hegel:

O princípio do Estado alemão original, que se estendeu desde a Alemanha a toda Europa, era o princípio da monarquia, a saber, um poder estatal sob um comando superior para a condução dos assuntos gerais, contando com a cooperação do povo, mediante seus representantes. A forma disto está, ela mesma, naquilo que se chama Dieta; mas a coisa (Sache) desapareceu (VD, p. 574; idem, p.146).

15 "Essa forma de direito político alemão é profundamente assentada naquilo que se tornou mais famoso nos alemães, ou seja, a sua inclinação à liberdade. Essa tendência é o que não tem permitido que os alemães constituam um povo submetido a uma autoridade política comum, depois que todos os demais povos europeus se submeteram à soberania do Estado unitário" (CA, p. 13; VD, p. 464).

$16 \mathrm{~N}$. Bobbio aponta como Hegel concorda, até certo ponto, com Montesquieu na noção de que a monarquia representativa é produto do povo alemão. Cf. Bobbio, 1989, p. 145-146. 
O mais problemático para Hegel era justamente o fato de a Alemanha não ter se configurado de acordo com o princípio da monarquia representativa. Prevalecia, na Alemanha do início do século XIX, a independência do povo em relação ao monarca e tal situação era totalmente avessa à proposta da organização representativa feudal na qual os indivíduos se agrupavam em estamentos sociais e eram representados por seus líderes nas assembleias imperiais (Dieta). ${ }^{17}$ Com o advento da modernidade, crescia o desejo pela liberdade e cada pessoa queria ter o poder político para representar a si mesma no Estado. Hegel acreditava ser impossível essa forma de representação democrática nas grandes províncias, pois a tendência dos homens livres de exigir que o governo fosse o grande protetor dos interesses particulares desviava o caráter originário da monarquia representativa alemã, a saber, a subordinação das partes ao todo, a conservação do direito privado no direito público (cf. CA, p. 29-30; VD, p. 479-478).

Nessa perspectiva, restava do Estado alemão original apenas a Constituição ideal do Império (monarquia representativa), que estava em oposição à Constituição real do Império daquele tempo (inexistência do Estado alemão representativo). Assim, fixa-se a contradição entre o real e o racional, entre a realidade positiva e o que deveria ser organizado segundo a racionalidade para a Alemanha tornar-se um Estado efetivo.

\section{0 jovem Hegel entre o positivismo e o jusnaturalismo}

$\mathrm{Na}$ tentativa de desfazer a oposição entre o real e o racional, o jovem Hegel já trilha na $C A$ os primeiros passos para chegar à conhecida premissa especulativa da sua obra Linhas Fundamentais da Filosofia do Direito ou Direito Natural e Ciência do Estado em Compêndio [Grundlinien der Philosophie des Rechts oder Naturrecht und Staatswissenschaft im Grundrisse-(1821)]: "o que é racional, isto é efetivo e o que é efetivo, isto é racional” (Hegel, 2010, p. 41). Esse enunciado expressa como na transformação da realidade é apreendido o movimento de efetivação da própria razão, em outras palavras, explicita a identidade necessária e imanente da vida prática e da vida teórica do espírito. Assim, ao discutir na CA o que é e como deveria ser o Estado alemão, Hegel analisa a contingência dos fatos visando compreender o que precisava permanecer e desaparecer no mundo moderno, não no sentido de fazer previsões futuras, mas na intenção de arrancar do próprio processo histórico a razão impulsionadora do povo alemão para a construção do Estado ético.

Diante disso, Hegel discordou de duas escolas jurídicas da sua época que não compreendiam a verdadeira síntese entre o ser e o dever ser. Debatendo

$17 \mathrm{H}$. Marcuse afirma que o jovem Hegel defendia o sistema feudal como sendo a representação da coletividade acima dos indivíduos: "O sistema feudal propriamente dito integrava os interesses particulares das diversas classes em uma verdadeira comunidade. A liberdade do grupo, ou do indivíduo, não se opunha de modo essencial à liberdade do todo" (Marcuse, 2004, p.57). 
com positivistas e jusnaturalistas, o jovem Hegel concluiu que, mesmo analisando por óticas diferentes as questões sobre o Estado e o direito, ambas as escolas permaneceram aferradas a princípios ilegítimos para fundar as leis e as instituições. Enquanto os positivistas analisavam empiricamente o Estado e nada mais faziam além de descrever em teorias abstratas aquilo que era, os jusnaturalistas articulavam o mundo da prática com base em ideias abstratas da razão, ficando restritos ao "dever ser formal".

Sobre os positivistas, explicita o jovem Hegel:

Os antigos mestres do direito constitucional não mais tratam o direito constitucional como uma ciência, mas como uma descrição do que, de modo empírico, há positivamente (vorhanden), mas que é incapaz de configurar-se de forma racional; pois creem que não podem fazer outra coisa, em relação ao Estado alemão, que the dar o nome de Império ou corpo político. Já não se discute acerca do conceito sob o qual se inclui a Constituição alemã, [pois] o que não pode chegar a ser concebido não existe de modo algum (VD, p.461; Hegel, 1972, p.146).

Os positivistas não se esforçavam para encontrar a razão, a necessidade nos próprios acontecimentos; ao contrário, tinham a visão limitada e não conseguiam enxergar o sentido da unidade política que pulsava na Alemanha em meio à multiplicidade de acontecimentos. Então, a única atitude desses teóricos era descrever empiricamente o Estado alemão, sem se preocupar com a contradição existente entre a forma da Constituição e o conteúdo da realidade alemã, que era a ausência da unidade política.

No que diz respeito aos jusnaturalistas, o jovem Hegel afirma que esses teóricos são dominados pelo pensamento formal, pois acreditavam na necessidade e na universalidade dos conceitos, a ponto de defenderem que o direito, o Estado e a liberdade deviam ser totalmente fundados nos puros princípios da razão. Ao que tudo indica, Hegel refere-se especificamente às doutrinas jusnaturalistas de Kant e Fichte, já que em outros escritos, como no artigo do Direito Natural (1802), ambos serão acusados de romper com o elo entre a necessidade do racional e a contingência dos fatos, entre o conceito e a intuição, entre o dever ser e o ser. Segundo Hegel:

Pois o que nos arrebata e faz-nos sofrer não é o que é, e sim o que não é como deveria ser; mas se reconhecemos que é como deve ser, quer dizer, não segundo a arbitrariedade e o acaso, então reconhecemos também que deve ser assim. No entanto, parece difícil aos homens, geralmente, elevar-se ao hábito de conhecer e pensar a necessidade. Pois, entre os fatos e o livre apreender dos mesmos, eles colocam um monte de conceitos e de fins e exigem que o que acontece esteja de acordo com eles; mas quando isso se dá de outra maneira, como, sem dúvida, acontece quase sempre, desculpam-se de seus conceitos, como se nestes dominasse a necessidade enquanto que, no entanto, naquilo que acontece somente dominasse 0 acaso (VD, p.463; Hegel, 1972, p.11).

Os alicerces do método especulativo hegeliano são apresentados ainda de modo mais claro na crítica aos jusnaturalistas: aquilo que é na sociedade e no 
Estado deve ser necessariamente assim. ${ }^{18}$ Hegel não estava preocupado em explicar simplesmente o que é e o que deveria ser no Estado alemão de acordo com as ideias abstratas da razão, todavia procurou reconhecer o que precisa ser necessariamente de acordo com o desenvolvimento efetivo da razão no mundo. Por isso, o nosso filósofo não pode concordar com os jusnaturalistas, pois eles contrastam a razão e a realidade, fundando a vida política nas leis formais do pensamento puro.

Com o propósito de pensar a efetividade do Estado ético e de reconhecer a razão especulativa nos acontecimentos políticos, Hegel irá prolongar em Jena o seu debate com os filósofos jusnaturalistas. No artigo Sobre as maneiras científicas de tratar o direito natural: seu lugar na filosofia prática e sua relação com as ciências positivas do direito (DN) [Über die wissenschaftlichen Behandlungsarten des Naturrechts, seine Stelle in der praktischen Philosophie, und sein Verhältnis zu den positiven Rechtswissenschaften- (NR) $]^{19}$, publicado em 1802, Hegel continua desenvolvendo algumas noções da Constituição da Alemanha, mas seu maior interesse é chegar cada vez mais próximo da ideia orgânica do Estado, ou melhor, da vida ética absoluta, espaço para a reconciliação efetiva do direito privado e do direito público.

0 principal interesse do direito especulativo hegeliano é apresentar as mediações para reconduzir os homens egoístas à vida ética no mundo moderno. Assim, na trilha da $C A$, o DN desenvolve a ideia de que as normas do direito privado não são as mediações exclusivas da identidade do indivíduo e da coletividade; na verdade, é o direito público que possibilita ao indivíduo a vida ética absoluta como local para efetivação da liberdade.

No $D N$, ao apresentar a relação entre o direito natural e o direito positivo, quer dizer, entre as regras abstratas universais e a concretude particular dos povos, 0

18 Conforme J.L. Hernández: "Hegel introduz então seu método dialético: declara que o objeto deste seu escrito é conhecer a realidade que é através de sua razão de ser ou de sua necessidade, quer dizer, compreender que o que é na realidade (was ist), tem que ser assim necessariamente (sein muss) e que, portanto, deve ser assim (sein soll). Desta forma, Hegel une o SER e o DEVER SER por meio do TER QUE SER: a necessidade ou a razão. Os jusnaturalistas colocavam o DEVER SER ou DIREITO DA RAZÃO como o verdadeiro, e os positivistas colocavam como verdadeiro o ser empírico do direito ou DIREITO POSITIVO. No entanto, ninguém concebia a verdade como a união do SER e o DEVE SER, compreendendo o SER como o empírico e o DEVER SER como o racional, que são dois aspectos do saber que estão sempre unidos nas coisas existentes. Agora, o existente em alemão se expressa de duas maneiras: se algo existe simplesmente, sem que tenhamos conhecimento de que é racional, autêntico ou verdadeiro, se denomina Dasein; se algo existe e é uma realidade cuja existência coincide com sua essência, então dizemos que tem razão ou que é autêntico e a isso se denomina wirklich. 0 real (wirklich) produz efeitos, é efetivo; o existente (Dasein) é um dado empírico, algo que existe, mas até que não se saiba sua verdadeira essência não sabemos qual é a sua eficácia. Hegel trata de conhecer a realidade efetiva do Estado alemão de seu tempo, a Constituição do Sacro Império, e descobre que esse Estado não é real (wirklich) e por isso diz que - já não existe (Deutschland ist kein Staat mehr). Os fatos não tardaram em confirmar que esta afirmação produzida segundo o novo método hegeliano era verdadeira (como se pôde comprovar em 1806)" (Hernández, 2009, p.77-78).

19 Utilizaremos a seguinte tradução brasileira da obra: Hegel, 2007. Indicaremos a seguinte versão da obra no original: Hegel, 1986. A tradução da citação do DN foi revisada pelo prof. Dr. Leonardo A. Vieira. 
jovem Hegel assume a hipótese fundamental de que o direito natural, embora tenha a pretensão de se configurar como sistema de princípios ético-jurídicos racionais e universais, somente tem sentido na positividade. Logo, o direito especulativo, enquanto a mediação necessária para a realização da vida ética absoluta, apenas tem efetividade na história dos costumes éticos e das leis de cada povo. E nos povos, é o próprio espírito do mundo, o Absoluto, que se expressa e se experimenta em maior ou menor grau nas figuras particulares da cultura (DN, p.127; NR, 522). Nesse sentido, cabe à doutrina do direito especulativo identificar a efetivação livre do espírito em determinada época regida por leis positivas.

Mesmo considerando a relevância da positividade do direito, o jovem Hegel lembra que a simples existência de um código jurídico positivo não é suficiente para realizar a vida ética absoluta, pois em muitos casos o direito positivo vigente em nada se relaciona com os princípios da razão e da liberdade. Na $C A$, Hegel já denuncia a contradição entre as leis aceitas na Alemanha no fim do século XVIII e a necessidade de unificação do povo alemão, chegando a afirmar o isolamento da Alemanha em relação ao espírito do mundo. No artigo do $D N$, é retomada essa mesma crítica para explicar que quando as leis positivas são estranhas ao espírito do mundo, o povo é dissolvido. Segundo Hegel:

Assim, num povo dissolvido, por exemplo, no povo alemão, as leis podem seguramente parecer ter verdade, se não se distingue se elas são leis do negativo e da separação ou leis do que é verdadeiramente positivo e da unidade. Imediatamente com isso que as leis organizando um todo têm significação apenas para um passado e referemse a uma figura e individualidade que, depois de muito tempo, é deixada como um invólucro morto, que elas ainda têm interesse apenas pelas partes e, por aí, não põem a relação viva a respeito do todo, mas uma autoridade e dominação estranha a ele (NR, 527; Hegel, 2007, p.132).

Frente ao exemplo do povo alemão, fica ainda mais evidente o interesse do direito especulativo em reunir o racional e o histórico, o ser e o dever ser, o universal e o particular, na unidade ética do povo. No contexto histórico, no qual as leis exercem poder estranho sobre os indivíduos, certamente, não existe um povo organizado na vida ética livre e justa, ao contrário, reina a desordem e a violência.

No seu projeto ético esboçado na $C A$ e, em certos aspectos, aprofundado no $D N$, o jovem Hegel reconheceu na sua época o que era como deveria ser: a Constituição do Estado alemão unificado e justo de acordo com o espírito do mundo, por isso concluiu: “A Alemanha não é mais um Estado”. Na Alemanha, a essência do Estado não coincidia com sua existência, a Constituição racional não se configurava na realidade do povo. Mesmo diante dessa preocupante constatação política, o jovem Hegel convidou seus compatriotas a descobrirem a razão do Estado alemão nele mesmo e, a partir daí, a realizarem o esforço para efetivar a vida ética no novo mundo. 


\section{Referências}

Bourgeois, B. (2000). O pensamento político de Hegel. Tradução brasileira de Paulo Neves da Silva. São Leopoldo, RS: UNISINOS.

Beckenkamp, J. (2004). Entre Kant e Hegel. Porto Alegre: EDIPUCRS.

Bobbio, N. (1989). Estudos sobre Hegel. Direito, Sociedade civil, Estado. Tradução brasileira de Luiz Sérgio Henrique e Carlos Nelson Coutinho. São Paulo: UNESP e Brasiliense.

Bicca, L. A. (1997). “Revolução Francesa na Filosofia de Hegel”. In: Racionalidade moderna e subjetividade. São Paulo: Loyola.

Habermas, J. (2013). “A crítica de Hegel à Revolução Francesa”. In: Teoria e práxis. Tradução brasileira de Rúrion Melo. São Paulo: Editora Unesp.

Hegel, G.W.F. (1971). „Die Verfassung Deutschlands (1800-1802)“. In: Frühe Schriften. Frankfurt am Main: Suhrkamp.

(1972). La Constitucion de Alemania. Tradução de Dalmacio Negro Pavon. Madrid: Aguilar.

(1986). „Über die wissenschaftlichen Behandlungsarten des Naturrechts, seine Stelle in der praktischen Philosophie, und sein Verhältnis zu den positiven Rechtswissenschaften“. In: Jenaer Schriften 1801-1807. Werk 2. Frankfurt am Main: Suhrkamp.

(1990). "Carta a Niethammer de 13 de outubro de 1806". In: Correspondance I. Paris: Gallimard.

. (1990). “Carta a Niethammer de29 deabril de 1814”. In: Correspondance II. Paris: Gallimard.

. (2004). "O mais antigo programa de sistema do Idealismo Alemão”. Tradução brasileira de Joãosinho Beckenkamp. In: Beckenkamp, J. Entre Kant e Hegel. Porto Alegre: EDIPUCRS.

- (2007). Sobre as maneiras científicas de tratar o direito natural: seu lugar na filosofia prática e sua relação com as ciências positivas do direito. Tradução brasileira de Agemir Bavaresco e Sérgio B. Christino. São Paulo: Loyola.

- (2010). Linhas Fundamentais da Filosofia do Direito ou Direito Natural e Ciência do Estado em Compêndio. Tradução brasileira de Paulo Meneses et al. São Leopoldo: UNISINOS.

Hernándes, J.L. (2009). El Pensamiento político del joven Hegel. Revista Anales de Drecho, Murcia, 27, pp.66-91.

Kant, I. (2002). A paz perpétua e outros opúsculos. Tradução portuguesa de Artur Morão. Lisboa: Edições 70.

Marcuse, H. (2004). Razão e Revolução: Hegel e o advento da teoria social. Tradução brasileira de Marília Barroso. São Paulo: Paz e terra.

Norbert, E. (1997). Os Alemães - a luta pelo poder e a evolução do habitus no séc. XIX e XX. Tradução brasileira de Álvaro Cabral. Rio de Janeiro: Zahar.

Oliveira, M. A. (1993). “A leitura hegeliana da Revolução Francesa”. In: Ética e Sociabilidade. São Paulo: Loyola. 
Ritter, J. (1970). Hegel et la Révolution Française. Paris: BEAUCHESNE.

Rosenzweig, F. (2008). Hegel e o Estado. Tradução brasileira de Ricardo Timm de

Souza. São Paulo: Perspectiva.

Recebido em: 18.12.2017

Aceito em: 20.06.2018 